\title{
The Impact of Typical Cemetery on Groundwater Using both Geophysical Techniques and Physicochemical Analyses of Water in South-South, Nigeria
}

\author{
Idehen, Osabuohien ${ }^{1}$ \\ ${ }^{1}$ Department of Physics, Faculty of Sciences, Tayo Akpata University of Education, Ekiadolor-Benin, Nigeria \\ Correspondence: Idehen, Osabuohien, Department of Physics, Faculty of Sciences, Tayo Akpata University of \\ Education, Ekiadolor-Benin, Edo State, Nigeria
}

Received: March 27, 2019; Accepted: May 7, 2019; Published: June 10, 2019

\begin{abstract}
This research work focuses on the impact of cemetery on the groundwater with respect to time. It was carried out using Joint Geophysical Methods and Hydro physicochemical analysis. In addition to these methods this study went further to apply Multivariate Statistical Analyses (Water Quality Index, Principle Component Analysis, Cluster Analysis) in the investigation. This research work was done in Third Cemetery, New Benin, Benin City. Though there are three major cemeteries in Benin Metropolis Third Cemetery was selected for this purpose. In Benin City and Nigeria in general, the major cemeteries are located close to human residential areas and virtually all the populace within this locality depends on groundwater as the primary water source for various domestic purposes. The spread of electrodes reaches a maximum of $230 \mathrm{~m}$ which covers the entire length of the cemetery. Electrodes (41) were needed in this research to generate data and the result compared with the physico-chemical analysis of groundwater. The field work covered a time lapse of six months (June, 2017 to December, 2017). Toxic chemicals that may be released into groundwater include substances that were used in embalming and burial practices as well as varnishes, sealers and preservatives and metal component of ornaments used on wooden coffins (Jonker and Olivier, 2012).Wood preservatives and paints used in coffin construction contain compounds such as copper, naphthalene and ammoniac or chromated copper arsenate (Spongberg and Becks, 2000). Paints contain lead, mercury, cadmium, and chromium; arsenic is used as a pigment, wood preservative and anti-fouling ingredient while barium is used as a pigment and a corrosion inhibitor (Katz and Salem, 2005; Huang et al., 2010; Jonker and Olivier, 2012).
\end{abstract}

Keywords: cemetery, groundwater, geophysical, physicochemical, leachate plume

\section{Introduction}

Agriculture, industry and landfills are commonly believed to be major anthropogenic sources of environmental contamination. Little attention has been given to cemeteries as possible pollution sources. The most common practice for disposal of dead bodies is inhumation in soil, which favours interactions with the surrounding environment. However when the burial ground is located where hydrogeological, geological and climatic conditions not favourable to the process, contamination of soils and groundwater may occur. The most critical parameters when assessing the pollution potential of a burial ground are inhumation depth, geological formation, depth of the water table, density of inhumations, soil type and climate.

Studies carried out from the contamination arising from cemeteries originated from minerals that are released by burial loads (Borsted and Niquette, 2000). The minerals that are needed in coffin-making may corrode or degrade releasing harmful toxic substances (Spongberg and Becks, 2000). These may be transported from the graves through seepage and diffuse into surrounding soils. From there they may leach into groundwater and become potential health risk to the residents on areas surrounding the cemetery (Jonker and Olivier, 2012; Engelbrecht, 2010; Dent and Knight, 1998; Kim et al., 2008 Williams et al., 2009; Canninga and Szmigina, 2010).

Most existing cemeteries were sited without thinking about the potential risks to the local environment or community (WHO Nancy Project Report-TARGET 23, 2000). Interment of bodies in cemeteries remains a widespread practice and the only alternative endpoint to dead bodies in Nigeria. In Nigeria, this practice had not been perceived as having a significant potential contaminant effect in the environment and especially the groundwater component. However, the implications of land utilization for burial of dead human bodies in the form 
of cemeteries and many cases associated with coffin and caskets used for interment of remains has received no consideration in Nigeria. According to DOC (2016), cemetery sites/graveyards have the potential to impact on the local water environment and in particular, the groundwater underlying such sites.

The identification of individual graves through geophysical techniques is relatively problematic and thus in the prospection of cemeteries and graves there are no rules or specific guidelines. The success of such a survey depends on the conservation of the graves, the various artifacts that may accompany a burial, the depth and dimensions of the burial, the environmental noise, the geology, etc.

\section{Study Area}

This study was conducted in Benin City located in south-south geopolitical zone of Nigeria. Benin City is the capital of Edo State, bounded by latitudes $06^{\circ} 06^{\prime} \mathrm{N}, 06^{\circ} 30^{\prime} \mathrm{N}$ and longitudes $005^{\circ} 30^{\prime} \mathrm{E}, 005^{\circ} 45^{\prime} \mathrm{E}$ and an area of about 500 square kilometers. The city is located within the rain forest ecological zone with annual mean temperature of $27.5^{\circ} \mathrm{C}$ (Ikhuoria, 1987) and an annual mean rain fall of about $2095 \mathrm{~mm}$ (Ikhile and Olorode, 2011).

Three cemeteries namely First, Second and Third cemeteries are located within this city. The Third cemetery which has existed for over 50 year was considered for this study because of its proximity to human residents. The cemetery which is the biggest among the cemeteries in Benin City covers an area of about 5.167 ha (Ibhadode et al., 2017). Three sampling sites in the periphery of the cemetery were used for the collection of water samples.

Site 1, S1, SAN from residence opposite the gate of the cemetery. (S1 - N06 21.354 E005 37.600$)$

Site 2, S2, from New Benin Police Station that was carved out of the cemetery.(S2 - N06 21.357 E005 ${ }^{\circ} 37.721$ )

Site 3, S3, Iyaba Street, behind the cemetery (S3 - N06 21.263 E005 37.734), and a Reference Site located at Isiohor, $4 \mathrm{Km}$ away from the cemetery. . Geological sitting of Benin City is underlain by sedimentary formation described by Short and Stauble (1967).

\subsection{Physical Characteristics of Study Area}

The study area is Benin City, the capital of Edo State. It is situated in the mid-western part (South-South) of Nigeria (Fig. 1)

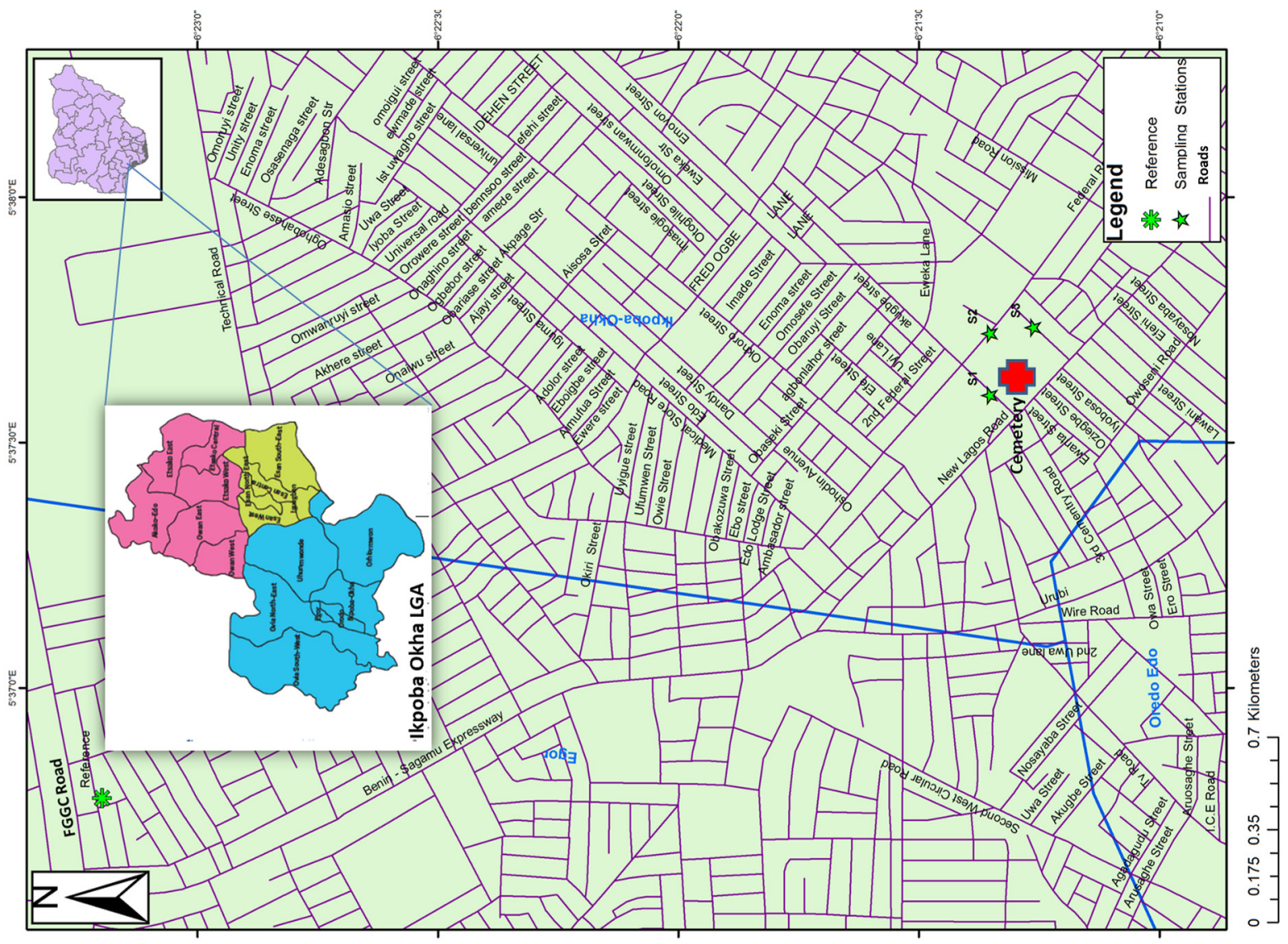

Figure 1. Map of the study area including sites of water samples collections 


\section{Methodology}

Electrical resistivity imaging data was acquired twice using Pasi Earth Resistivity Meter. The second data set was acquired six months after the first one. The data coverage was made over an area defined by rectangular loop measuring $30 \mathrm{~m}$ by $230 \mathrm{~m}$ in the first survey while in the second survey was $30 \mathrm{~m}$ by $200 \mathrm{~m}$. The electrical resistivity data was collected in seven equidistant lines as 2-D data set using Wenner-Schlumberger Array at $5 \mathrm{~m}$ interval in both periods. The first survey, the inter-electrode spacing in each line was $10 \mathrm{~m}$ while in the second survey was $5 \mathrm{~m}$.

The processed data depicted clearly the locations of low resistivity which occur at depths below $5.19 \mathrm{~m}$ and $2.60 \mathrm{~m}$ in the first and second surveys that are most likely to indicate accumulation of leachate plumes. The electrical resistivity data collected in parallel equidistant lines was processed to obtain geoelectric models using res2dinv and the second survey data set was also merged and inverted as a single 3-D data set using Res3dinv software, which is then visualized in detail using Voxler 4.0.

The plumes labeled L1-PL1, L1- PL2, L2-PL1, L3-PL1, L3-PL2, L4-PL and L7-PL observed in June 2017 2-D ERT images between the depth $5.19 \mathrm{~m}$ and $17.3 \mathrm{~m}$ were also observed in the Dec 2017 ERT Images. Thus, the areal extents and 3-D Models of these plumes were done in Res3dinv window and Voxler4.0 window.

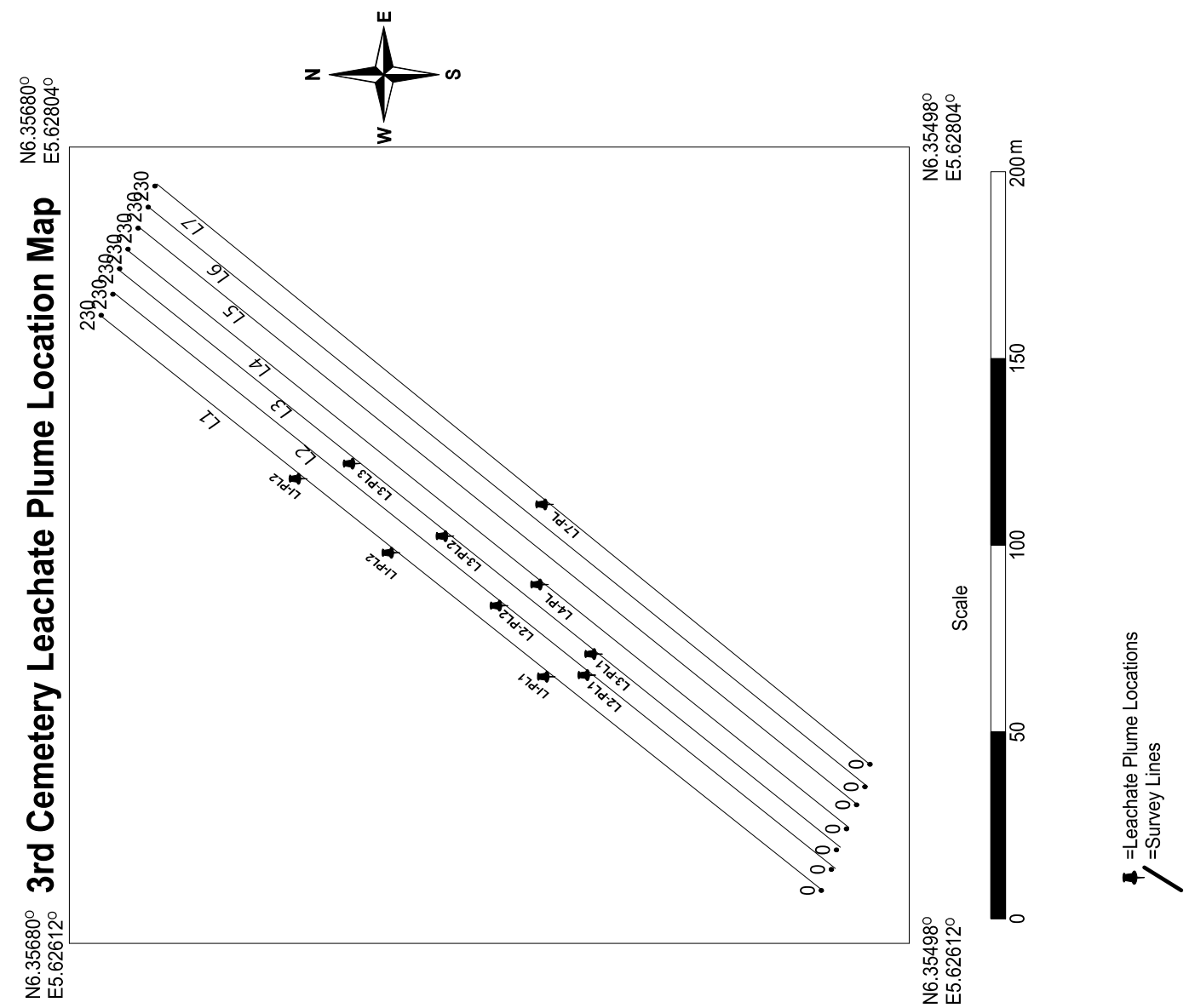

Figure 2. Surfer Plot of $3^{\text {rd }}$ Cemetery Leachate Plume Locations

\section{Discussion of Geophysical Tomography}

The water table likely occurs between the very coarse sand and medium sand. As leachate plume is detected in the medium sand, water in the well sorted coarse sand will be contaminated. The field works were conducted in two sessions with a time interval of six (6) months. The first ERT survey was conducted in June 2017 and the second ERT survey was conducted in December 2017.

The rate of migration depends on the permeability of the soil, incline topography, depressions created by decomposed corpses and collapsed burial materials. All these aid infiltration into the subsurface. 
The geoelectric models obtained for the first and second surveys displayed leachate plumes starting from the laterite (the burial environment) down to the sandy formation (the regional water supply source). The leachate plumes presence in the sand bed are modeled and described as shown in the 2-D and 3-D displays (Fig. 3 to Fig. 8, Idehen, 2018).
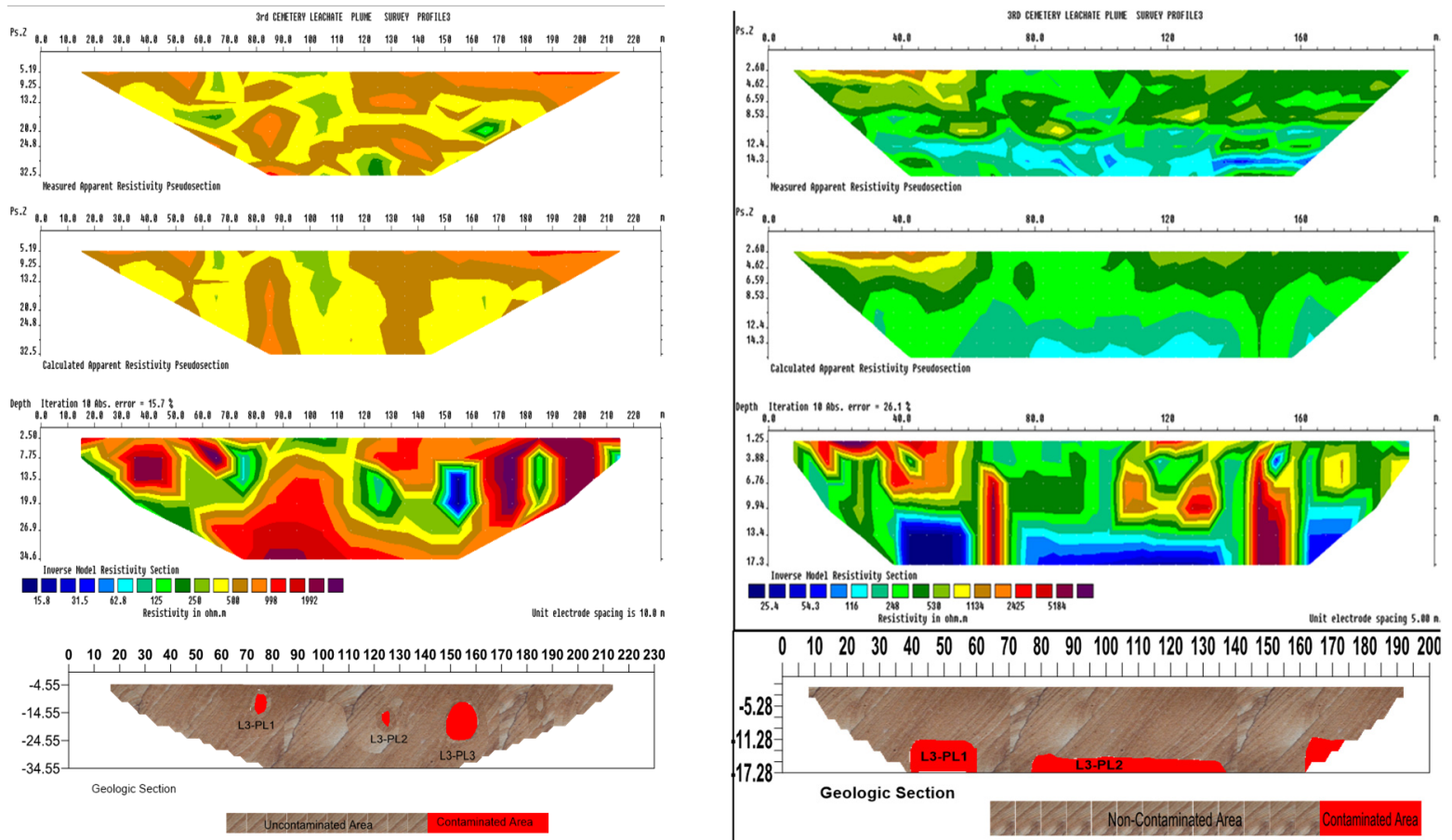

First Survey Profile3 (June, 2017)

Second Survey Profile3 (Dec. 2017)

Figure 3. 2-D Geoelectric Models of Profile3 in the First and Second Survey
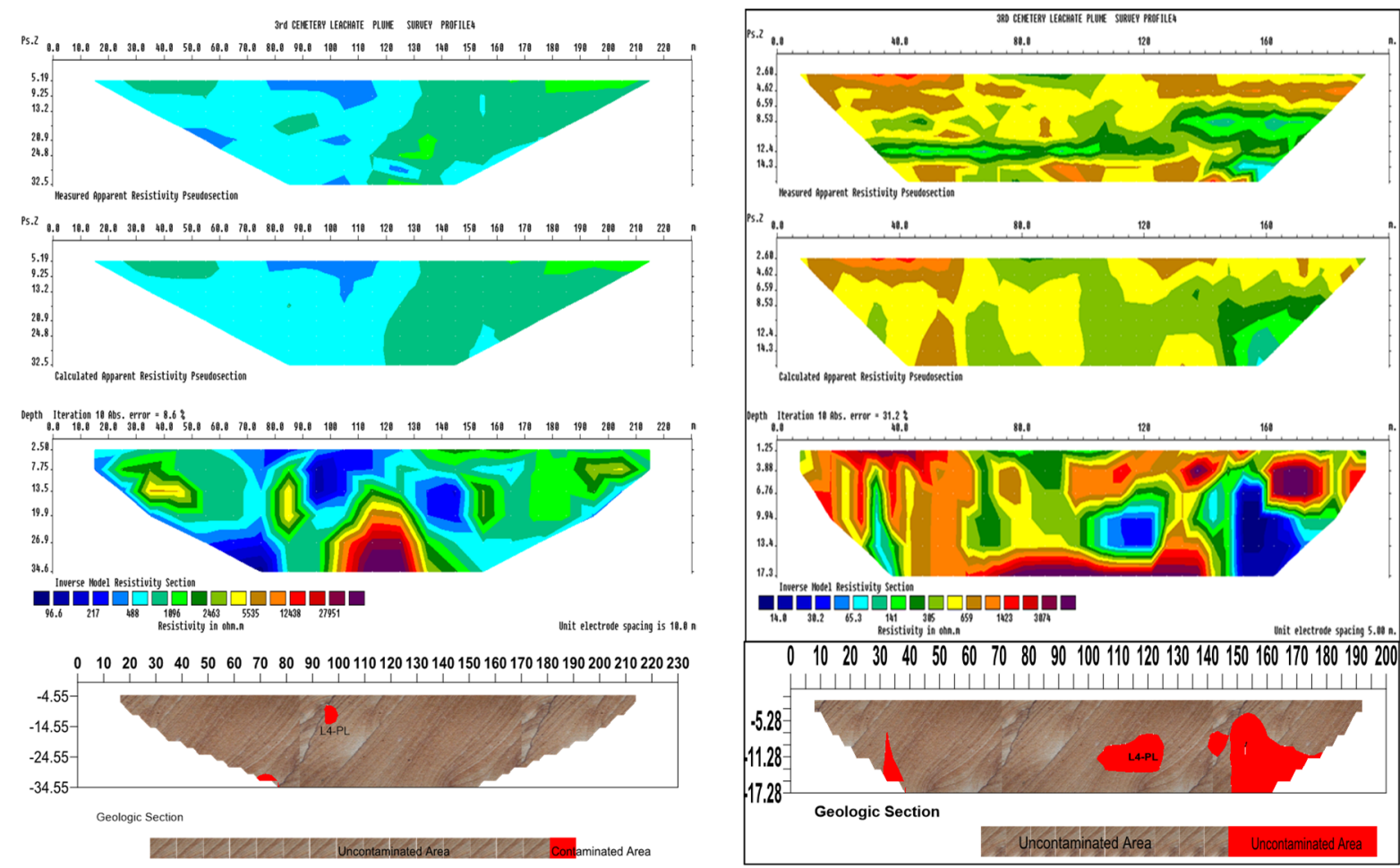

First Survey Profile 4 (June, 2017)

Second Survey Profile 4(Dec. 2017)

Figure 4. 2-D Geoelectric Models of Profile 4 in the First and Second Survey 


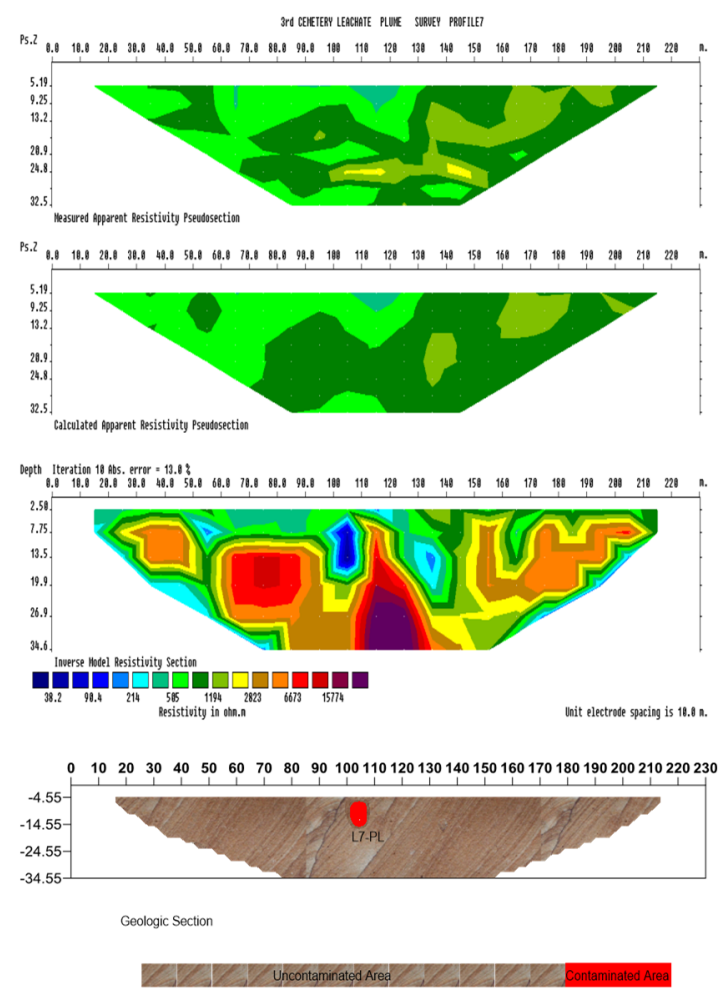

First Survey Profile 7 (June, 2017)
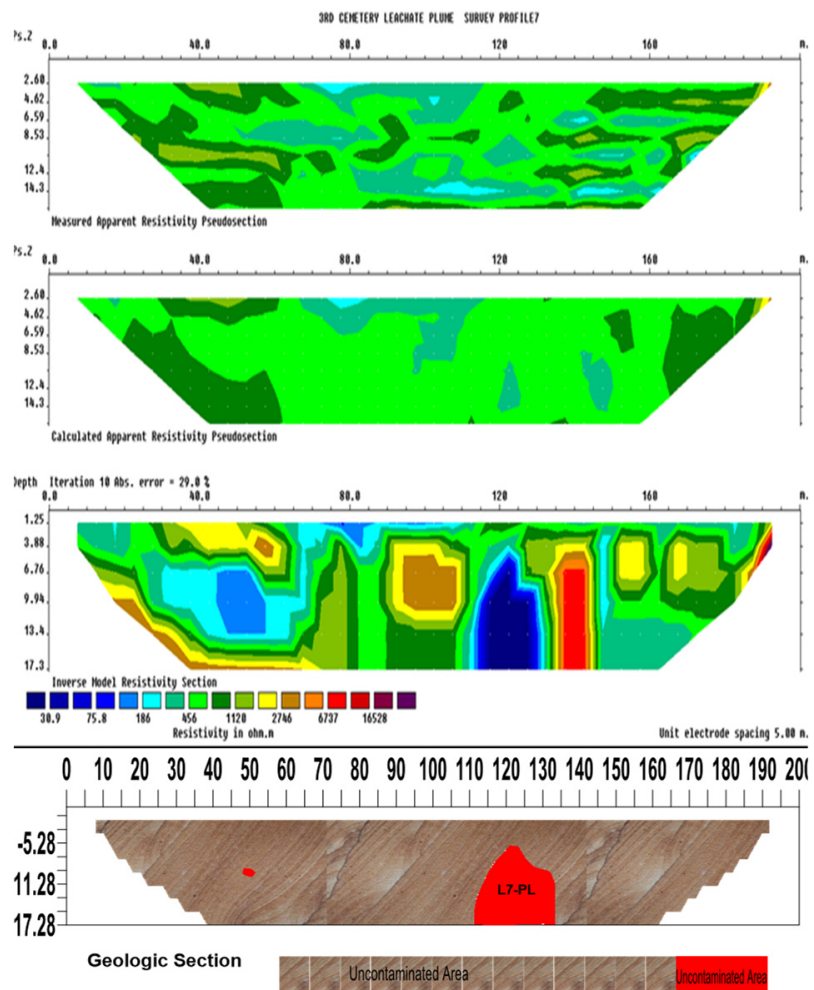

Second Survey Profile 7 (Dec. 2017)

Figure 5. 2-D Geoelectric Models of Profile 7 in the First and Second Survey

Voxler 4.0 command was used to obtain volume of the subsurface sediment contaminated by leachate plume. The volumetric analysis of the plume zones indicate that of the $75,231 \mathrm{~m}^{3}$ of the subsurface imaged, $6,322 \mathrm{~m}^{3}$ is the zone contaminated by leachate plume that is $8.4 \%$ of the earth volume investigated contain leachate plume.
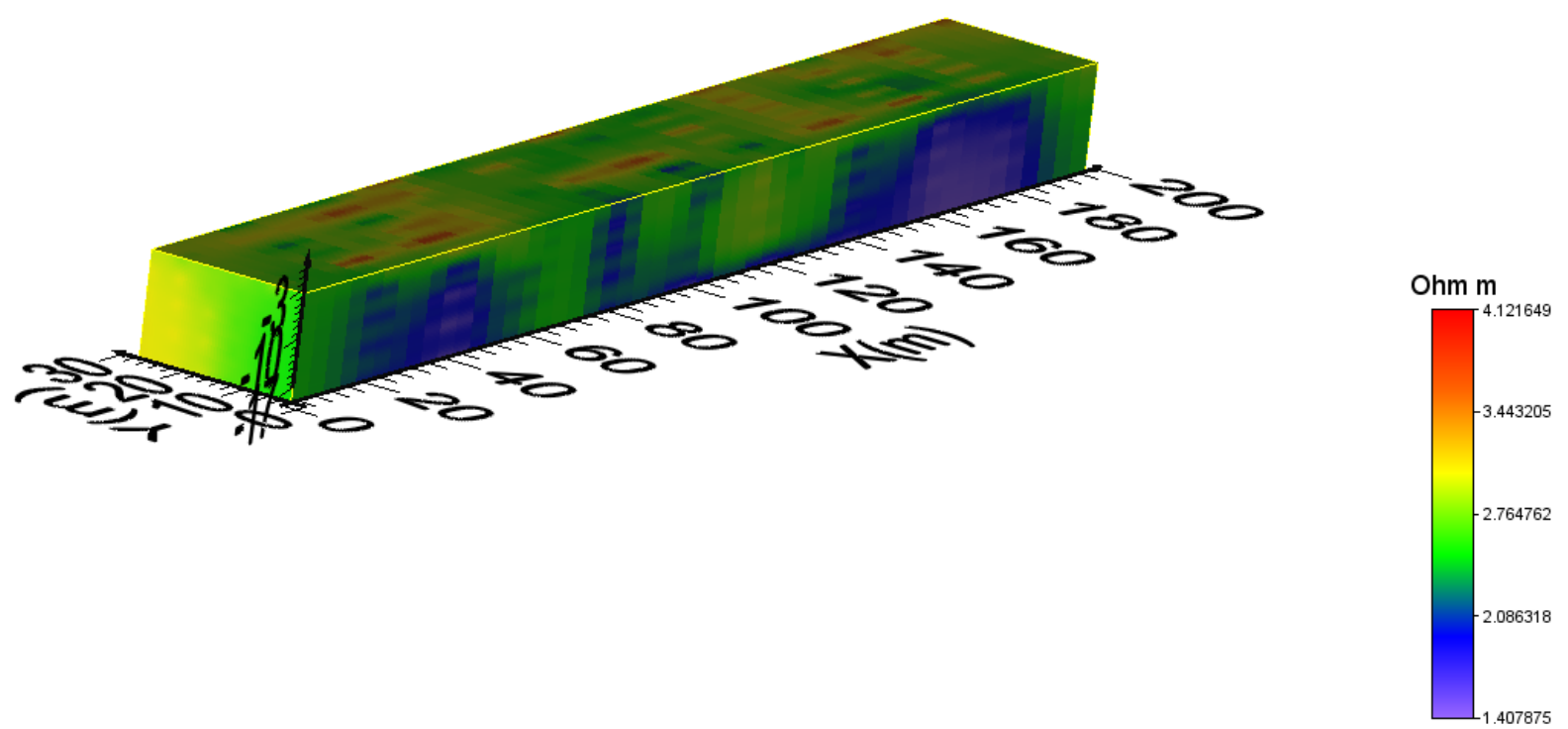

Figure 6. 3-D Face Render of the Earth Volume Investigated 


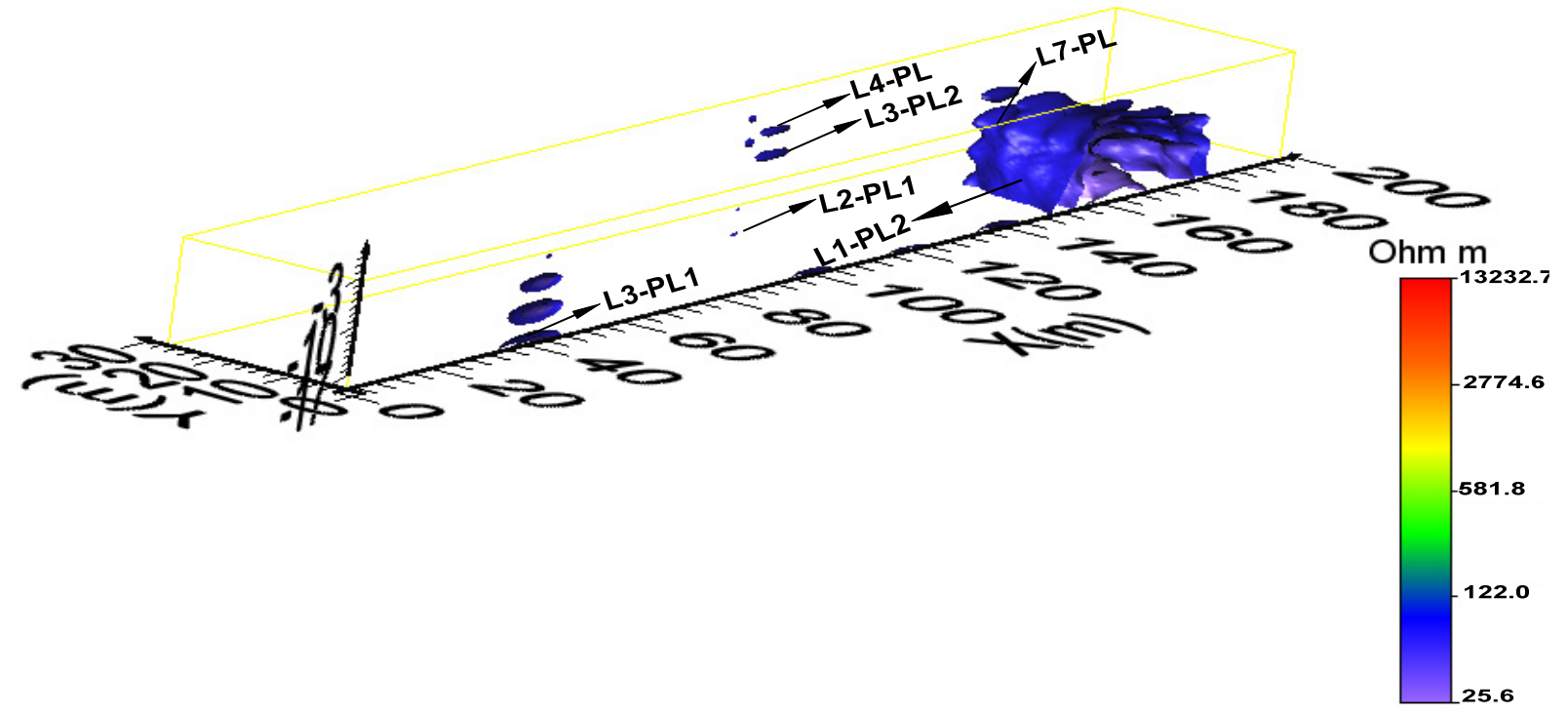

Figure 7. 3-D Resistivity distributions of Leachate plume zones

Table 1. Summary of variations in the physicochemical variables

\begin{tabular}{lllllll}
\hline Variables & Site 1 & Site 2 & Site 3 & Reference & CV & NSDQW \\
\hline Ph & 4.96 & 4.34 & 4.05 & 6.80 & 24.51 & 7.50 \\
EC & 118.00 & 82.00 & 160.00 & 12.00 & 67.43 & 1000.00 \\
TDS & 59.00 & 41.00 & 80.00 & 6.30 & 67.04 & 500.00 \\
TSS & 0.58 & 0.07 & 0.66 & 0.00 & 103.80 & 0.00 \\
Calcium & 3.84 & 3.20 & 4.48 & 2.40 & 25.56 & NA \\
Magnesium & 1.15 & 2.30 & 3.84 & 3.00 & 44.25 & 0.20 \\
Sulphate & 0.17 & 0.25 & 0.00 & 0.43 & 83.75 & 100.00 \\
Nitrate & 0.29 & 1.37 & 1.75 & 0.08 & 93.23 & 50.00 \\
Phosphate & 0.64 & 0.83 & 0.33 & 0.24 & 53.65 & NA \\
Calcium carbonate & 30.50 & 24.40 & 18.60 & 50.80 & 45.11 & 150.00 \\
Chloride & 44.52 & 23.78 & 36.40 & 18.40 & 38.57 & 250.00 \\
Sodium & 37.60 & 16.40 & 32.00 & 2.60 & 71.43 & 200.00 \\
Potassium & 48.88 & 21.32 & 41.60 & 3.38 & 71.43 & NA \\
Lead & 0.01 & 0.00 & 0.01 & 0.00 & 115.01 & 0.01 \\
Chromium & 0.01 & 0.01 & 0.01 & 0.01 & 0.00 & 0.05 \\
Copper & 0.02 & 0.01 & 0.03 & 0.01 & 81.65 & 1.00 \\
Zinc & 0.02 & 0.01 & 0.02 & 0.02 & 28.57 & 3.00 \\
Iron & 0.04 & 0.02 & 0.03 & 0.08 & 61.88 & 0.30 \\
Manganese & 0.03 & 0.01 & 0.02 & 0.01 & 81.65 & 0.20 \\
Cadmium & 0.00 & 0.00 & 0.00 & 0.00 & 0.00 & 0.00 \\
Nickel & 0.01 & 0.01 & 0.02 & 0.01 & 70.71 & 0.02 \\
Mercury & 0.00 & 0.00 & 0.00 & 0.00 & 0.00 & 0.00 \\
DO & 8.80 & 6.20 & 9.80 & 9.20 & 18.68 & NA \\
BOD5 & 2.60 & 1.80 & 3.40 & 0.60 & 56.88 & NA \\
COD & 12.46 & 10.32 & 14.77 & 12.10 & 14.74 & NA \\
\hline
\end{tabular}

NSDWQ - Nigerian Standard for Drinking Water Quality (NIS, 2007).

All variables except $\mathrm{pH}$ and $\mathrm{EC}$ were measured in $\mathrm{mg} / \mathrm{l}$; EC was measured in $\mu \mathrm{S} / \mathrm{cm}$ 
$\because \mathrm{PC} 1 \backsim \mathrm{PC} 2 \backsim \mathrm{PC} 3$

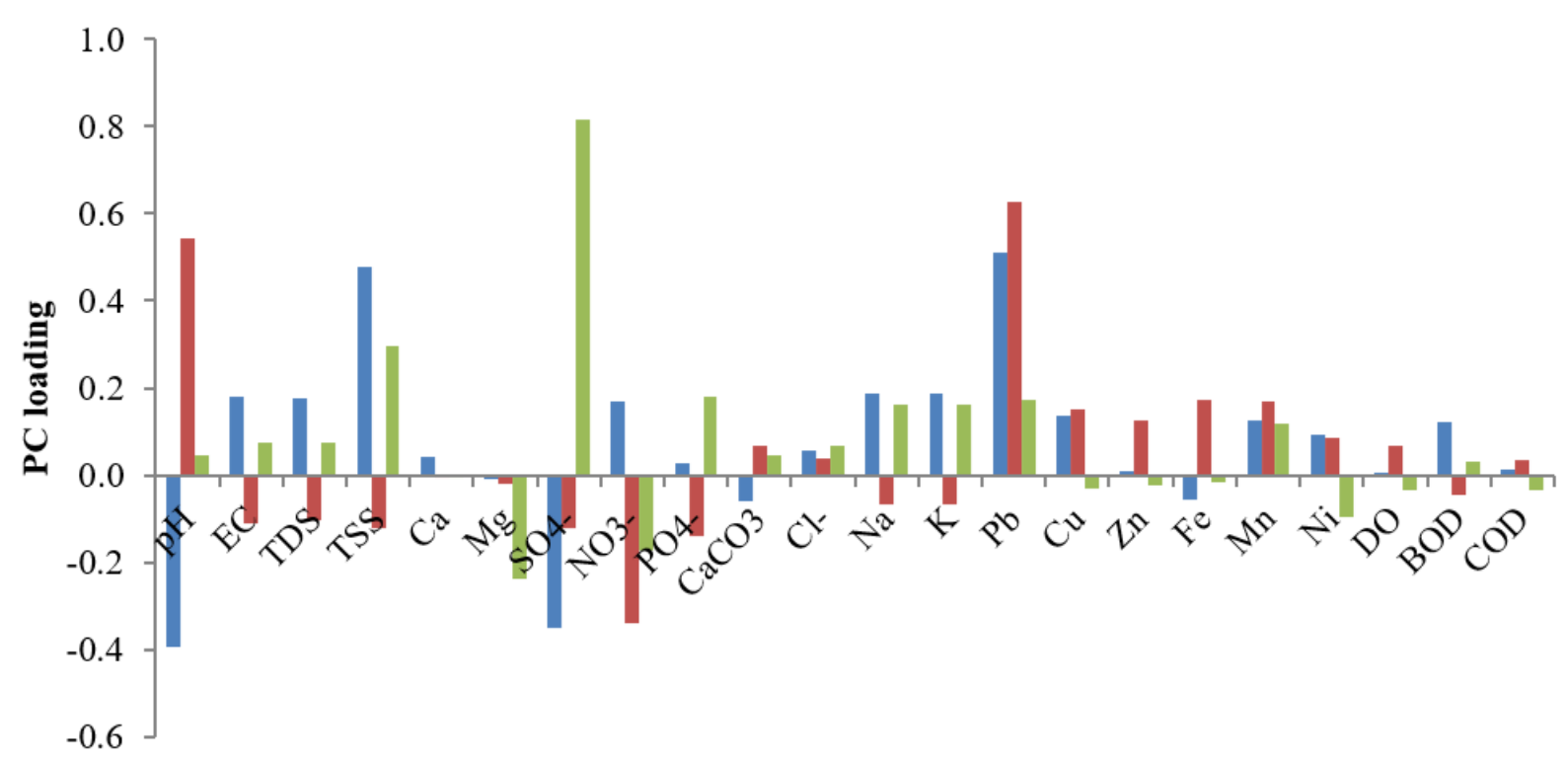

Figure 8. PCA loading across principle component (PC) 1, 2 \& 3.

In line with the descriptive and multivariate analyses adopted in this study, certain defined differences were recorded when the groundwater quality at the cemetery peripheral was compared to the reference site. High value magnitudes were obtained in groundwater samples obtained from cemetery peripheral compared to the reference. The likely implications of low pH values should be of concern, many metals including (heavy metals) stay dissolved in low $\mathrm{pH}$ (Winter et al., 1998) hence the availabilities which for some heavy metals ( $\mathrm{Pb}, \mathrm{Hg}, \mathrm{Cr}, \mathrm{Mn}$, $\mathrm{Cd}, \mathrm{Cu}, \mathrm{Ni}$ ) are deleterious to human health is enhance (Hammer and Hammer, 2004; Bakare-Odunola, 2005). Cr has been identified as carcinogenic agents, $\mathrm{Cd} \& \mathrm{Mn}$ as nephrotoxic agents, $\mathrm{Hg}$ as nephrotoxic and neurotoxic, and $\mathrm{Pb}$ as neurotoxic and enzyme inhibitor (NIS, 2007; Ernest, 2010). Generally the levels of all parameters with defined standard according to Nigerian Standard for Drinking Water Quality (NSDWQ) complied favourably across the sites

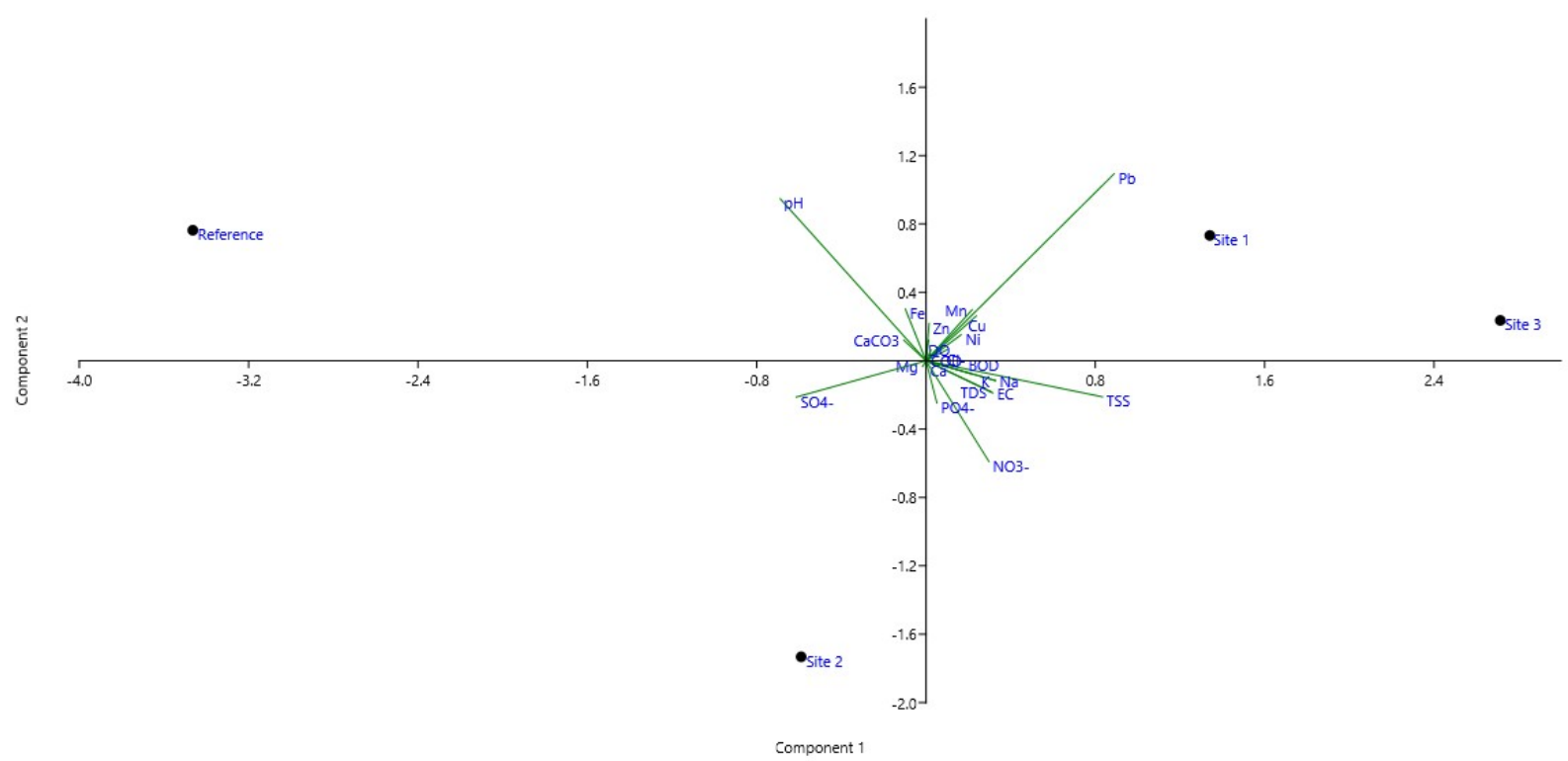

Figure 9. Plot of PCA loadings on parameters characterized in groundwater samples obtained from the various sites 


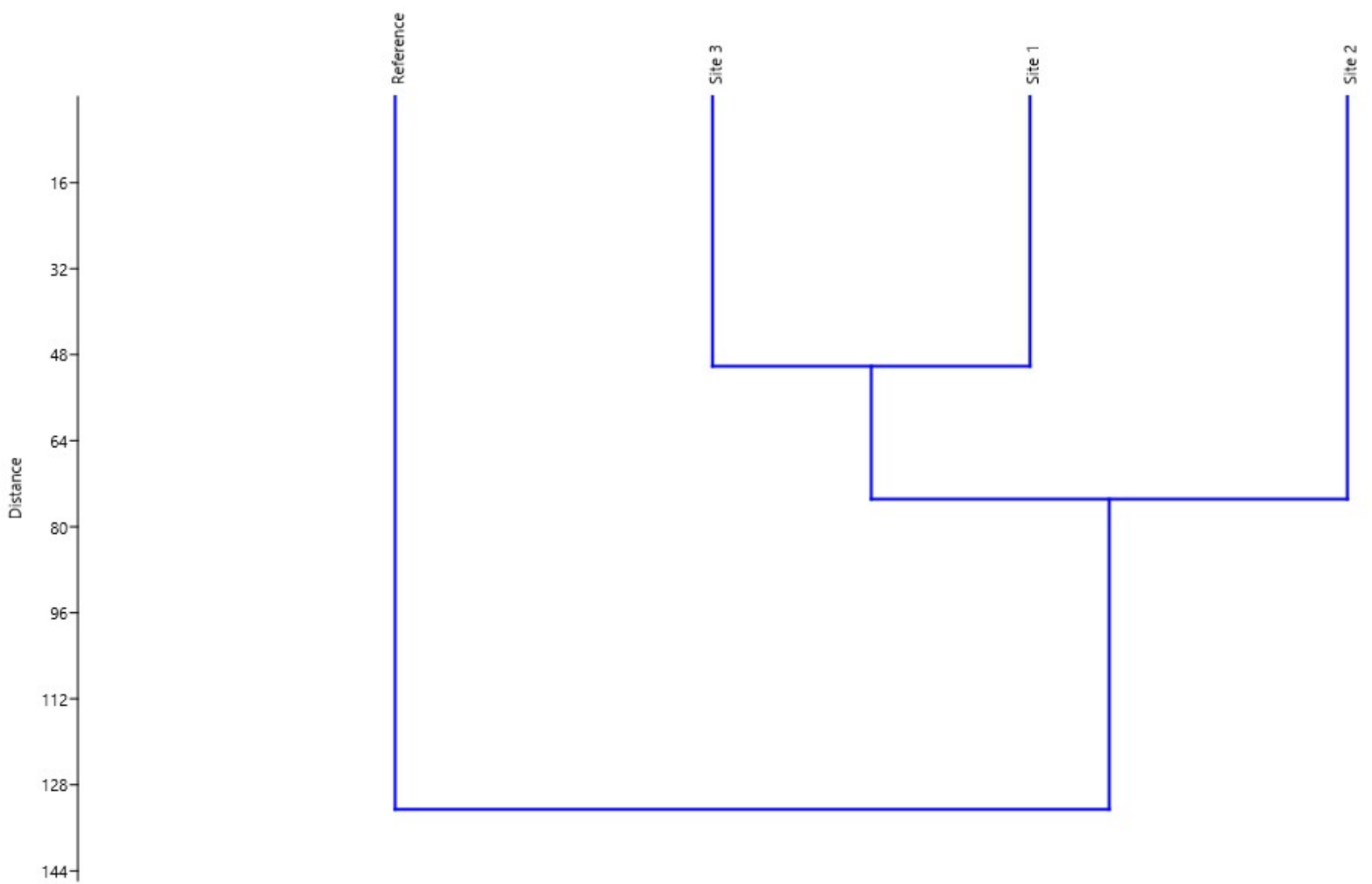

Figure 10. Dendogram for cluster analysis based on the concentrations of all the parameters.

- All parameters aSelected parameters

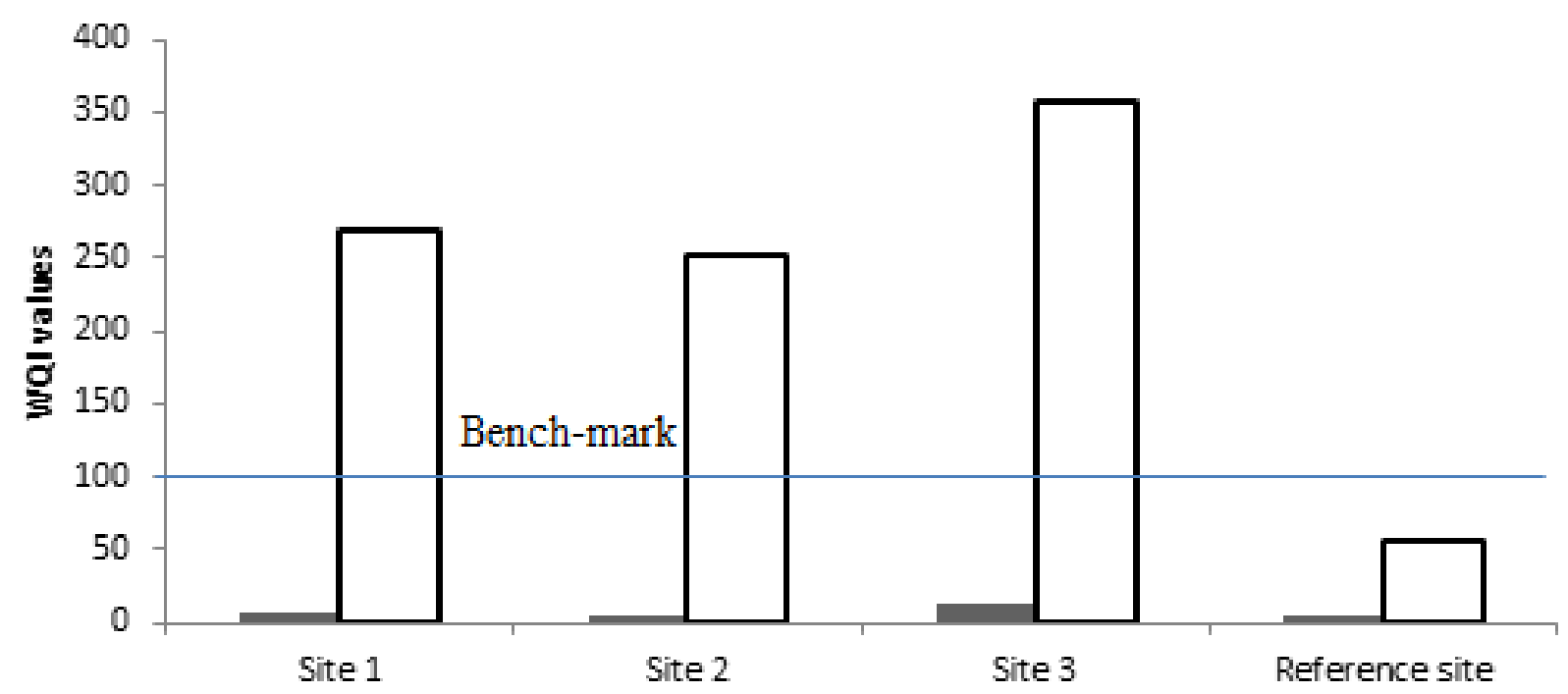

Figure 11. WQI spatial variations in relation to the parameters used in the computation

(Fig. 8 - Fig. 11, Idehen and Ezenwa, 2019)

Sites 1 and 3 recorded the highest levels in gross variation of analyzed parameters when compared to the reference site. The grouping of the sites as captured by dendogram implies that sites 1 and 3 share the same aquifer which is likely to be partitioned from site 2 .

The common parameters influenced by decomposing activities in cemeteries include $\mathrm{pH}, \mathrm{BOD}_{5}$, ammoniacal nitrogen, DO, EC, TOC, COD, $\mathrm{Cl}, \mathrm{NO}_{3}, \mathrm{SO}_{4}, \mathrm{P}, \mathrm{Na}, \mathrm{K}, \mathrm{Ca}$ and Fe (Üçisik \& Rushbrook 1998; Young et al., 2002; Sawyer et al., 2003; Tredoux et al., 2004). With the exception of $\mathrm{pH}, \mathrm{DO}, \mathrm{SO}_{4}$ and $\mathrm{Fe}$ the other parameters 
including $\mathrm{Cl}, \mathrm{NO}_{3}, \mathrm{Na}$, and $\mathrm{K}$ were generally higher in the groundwater samples obtained from sites at cemetery peripheral when compared to the reference site.

Tredoux et al., (2004) suggested the inclusion of $\mathrm{Mn}, \mathrm{Cd}, \mathrm{Cr}, \mathrm{Cu}, \mathrm{Ni}, \mathrm{Pb}$ and $\mathrm{Zn}$ at high risk sites; these heavy metals especially $\mathrm{Pb}, \mathrm{Mn}, \mathrm{Cu}, \mathrm{Ni}$ and $\mathrm{Zn}$ were the most influencing parameters related to sites $1 \& 3$. These changes together with other variations discussed above can be seen as clear indications of the impact of the decomposing activities in the cemetery upon the quality of the water in aquifer underlain the area. In an attempt to further assess the impact of common contaminants arising from decomposing activities in cemeteries, the WQI was computed restricting the parameters to $\mathrm{BOD}_{5}, \mathrm{Cl}, \mathrm{NO}_{3}, \mathrm{SO}_{4}, \mathrm{Na}$ and $\mathrm{K}$. Considering these variables, the computed WQI values scaled above the score of 100 for all sites except reference site. The high values of WQI obtained from these sites were primarily factored by $\mathrm{BOD}_{5}$ loads. In general, defined variations were observed when the parameters characterized in the groundwater samples were compared between the reference site and sites at cemetery peripheral.

\section{Conclusion}

The study clearly revealed that the status of the groundwater at the vicinity of Third Cemetery is fit or suitable for drinking and other domestic purposes though with some degree of contaminations. Under favourable hydrological and geological conditions, the plumes delineated from the Electrical Resistivity Imaging will slowly migrate into the groundwater. The maximum migration rates in the vertical and horizontal directions are $4.1 \mathrm{~cm} / \mathrm{day}$ and 32.8 $\mathrm{cm} /$ day respectively.

\section{References}

Bakare-Odunola, M. T. (2005). Determination of some metallic impurities present in soft drinks marketed in Nigeria. The Nig. J. Pharm, 4(1), 51-54.

Borstel, C. L., \& Niquette, C. (2000). Testing Procedure for Historic Cemeteries; Cultural Resource Analysts, inc.: Lexington, KY, USA.

Canninga, L., \& Szmigina, I. (2010). Death and disposal: The universal, environmental dilemma. J. Market. Manag, 26, 1129-1142. https://doi.org/10.1080/0267257X.2010.509580

Cude, C. (2001). Oregon water quality index: A tool for evaluating water quality management effectiveness. $J$. Amer. Water Res. Ass., 37, 125-137. https://doi.org/10.1111/j.1752-1688.2001.tb05480.x

Dent, B. B., \& Knight, M. J. (1998). Cemeteries: A special kind of landfill. Groundwater: Sustainable Solutions, Conference of the International Association of Hydrogeologists, Melbourne, pp. 451-456.

DOC. (2016). Cemeteries, Burials and the Water Environment; A good practice guide for applicants and planning authorities when planning cemetery developments or extensions. Practice guide. Version 1.1. NIEA Natural Heritage Division, Belfast BT7 2JA.

Engelbrecht, P. (2010). Ground Water Pollution from Cemeteries-A Case Study. In Proceedings of Environmental: Situation and Perspectives for the European Union, Porto, Portugal, 6-10.

Ernest, H. (2010). A textbook of modern toxicology. John Wiley \& Sons, Inc., Hoboken, New Jersey. 648 pp.

Hammer, M. J., \& Hammer, M. J. (2004). Water Quality. In: Water and Wastewater Technology. 5th Edition. New Jersey: Prentice-Hall, pp. 139-159.

Huang, S. L., Yin, C. Y., \& Yap, S. Y. (2010). Particle size and metals concentrations of dust from a paint manufacturing plant. J. Hazard. Mater., 174, 839-842. https://doi.org/10.1007/s11069-010-9509-6

Ibhadode, C. A. E., Dirius, A. R., \& Akhimien (2017). Adequacy or otherwise of cemetery space for sustainable human body disposal in Benin City, Nigeria. Ethiopian Journal of Environmental Studies \& Management, 10(5), 566-571.

Idehen, O. (2018). Time Lapse Geoforensic Investigation of Leachate Plume Migration from Active Cemetery in Benin City, Nigeria. Ph.D Thesis, University of Benin.

Idehen, O., \& Ezenwa, I. M. (2019). Influence of Third Cemetery Location on the Quality of Domestic and Groundwater Resources in Benin City, Nigeria. Journal of Applied Sciences and Environmental Management, 23(1), 5-11. ISSN 1119-8362. https://doi.org/10.4314/jasem.v23i1.1

Ikhile, C. I., \& Oloriode, D. O. (2011). Impact of climate change on underground-water resources development in Benin-Owena River basin, Edo State, Nigeria: case study. European Journal of Scientific Research, 63(2), 272-278. 
Ikhuoria, I. A. (1987). Urban land use patterns in traditional Nigeria City: A case study of Benin City. Land use policy, Great Britain, 4(1), 62-75. https://doi.org/10.1016/0264-8377(87)90009-3

Jonker, C., \& Olivier, J. (2012). Mineral Contamination from Cemetery Soils: Case Study of Zandfontein Cemetery, South Africa. Int. J. Environ. Res. Public Health, 9, 511-520. https://doi.org/10.3390/ijerph9020511

Katz, S. A., \& Salem, H. (2005). Chemistry and toxicology of building timbers pressure-treated with chromated copper arsenate: A review. J. Appl. Toxicol., 25, 1-7. https://doi.org/10.1002/jat.1005

Kim, K. H., Hall, M. L., Hart, A., \& Pollard, S. J. (2008). A survey of green burial sites in England and Wales and an assessment of the feasibility of a groundwater vulnerability tool. Environ. Technol, 29, 1-12. https://doi.org/10.1080/09593330802008404

Murray, R. C., \& Tedrow, J. C. F. (1975). Forensic Geology: Earth Sciences and Criminal Investigation. Rutgers University Press, New Brunswick, New Jersey. ISBN 978-06-8135-0794-1.

Nigerian Industrial Standard NIS 554. (2007). Nigerian Standard for Drinking Water Quality ICS 13, 060.20 (c) SON 2007.

Sawyer, C. N., McCarthy, P. L., \& Parkin, G. F. (2003). Chemistry for Environmental Engineering and Science. $5^{\text {th }}$ ed. McGraw-Hill, New York, 752 pp.

Spongberg, A. L., \&Becks, P. (2000). Organic Contamination in Soils Associated with Cemeteries. Journal of Soil Contamination, 9(2), 87-97. https://doi.org/10.1080/10588330008984177

Tredoux, G., Cavé, L., \& Engelbrecht, P. (2004). Groundwater pollution: Are we monitoring appropriate parameters? Water SA, 30(5) (Special edition), 114-119. https://doi.org/10.4314/wsa.v30i5.5180

Ucisik, A. S., \& Rushbrook, P. (1998). The impact of cemeteries on the environment and public health - an introduction briefing. WHO, Regional Office for Europe, World Health Organization. Rept. EUR/ICP/EHNA 010401 (A), 1-11.

Williams, A., Temple, T., Pollard, S., Jones, R., \& Ritz, K. (2009). Environmental considerations for common burial site selection after pandemic events. In Criminal and Environmental Soil Forensics; Ritz, K., Dawson, L., Miller, D. Eds.; Springer: The Netherlands; pp. 87-101. https://doi.org/10.1007/978-1-4020-9204-6_7

Winter, T. C., Harvey, J. W., Franke, O. L., \& Alley, W. M. (1998). Ground water and surface water a single resource. U.S. geological survey circular 1139. Denver, Colorado. https://doi.org/10.3133/cir1139

World Health Organization. (WHO) (2000). Regional Office for Europe, European Centre for Environment and Health, Nancy Project Office. The Impact of Cemeteries on the Environment and Public Health-TARGET 23: Waste Management and Soil Pollution; WHO Regional Office for Europe, European Centre for Environment and Health, Nancy Project Office: Copenhagen, Denmark.

Young, C. P., Blackmore, K. M., Leavens, A., \& Reynolds, P. J. (2002). Pollution Potential of Cemeteries. Environment Agency England and Wales. Retrieved from https://www.gov.uk/government/uploads/system/uploads/attachment_data/file/290607/sprp2-024-1-e-e.pdf

\section{Copyrights}

Copyright for this article is retained by the author(s), with first publication rights granted to the journal.

This is an open-access article distributed under the terms and conditions of the Creative Commons Attribution license (http://creativecommons.org/licenses/by/4.0/). 